\title{
Sobre o alcance teórico do conceito "exclusão"
}

\author{
Avelino da Rosa Oliveira ${ }^{1}$
}

Nas ciências sociais das últimas décadas é nítida a tendência a um uso indiscriminado, portanto, indefinido e impreciso, do termo exclusão. Esta situação já foi denunciada - não sem certa dose de ironia - como um dos novos eufemismos (Toledo, 1998) da arte de governar e administrar os conflitos de classe. "O que tudo isso quer dizer é que quando é difícil modificar a sociedade, ou o governo, modifica-se a linguagem." (p. 154) No mesmo tom,

\footnotetext{
${ }^{1}$ Doutor em Educação pela Ufrgs, com a tese Educação e exclusão: uma abordagem ancorada em Karl Marx (2002), professor de Filosofia da Educação na Univ. Federal de Pelotas; é o atual coordenador do GT Filosofia da Educação na ANPed e editor do periódico Cadernos de Educação, da FaE/UFPel. Publicou Marx e a Liberdade (Edipucrs, 1997), Educação e exclusão: a contribuição da Filosofia da Educação na determinação conceptual (Perspectiva, n.34, 2000), Exclusão sociale educação: um novo paradigma? (Educação \& Realidade, 1999), Exclusão Social - o que ela expli$c a$ ? (In: O mesmo e o outro da cidadania, L\&PM, 2000), A atualidade produtiva do pensamento de Karl Marx (In: As Portas de Tebas, Ed. UPF, 2002), A liberdade e o capital: ética pelo avesso (In: Ética, Seiva Ed., 2003), entre outros. Endereço: avelino.oliveira@ufpel.edu.br
}

Civitas, Porto Alegre, v. 4, nº 1, jan.-jun. 2004 
Veríssimo (1999) dá o toque humorístico final: "Eufemismo, tufemismas mas ninguém femisma como eles. (...) 'Excluído' é uma palavra a caminho da obsolência. (...) Deve ser substituída por 'colateral'. No mundo monopolar do sucesso liberal, existem os incluídos e existem os colaterais." (p. 3)

$\mathrm{Na}$ verdade, a partir do último quarto do século $\mathrm{XX}$, o termo exclusão começou, gradualmente, a ocupar espaços na literatura social, especialmente a partir da área das políticas públicas. Hoje, está fortemente presente em todas as áreas. Na maioria das ciências sociais, é empregado como se fosse um conceito científico de uso corrente, que já não mais precisasse ser definido; no campo das políticas públicas e da assistência social, constitui-se, inconfundivelmente, em alvo prioritário das ações; até mesmo certos movimentos religiosos, cujo conceito de "pobre" transcende o significado sociológico, renderam-se ao magnetismo do "excluído". Quem são, entretanto, os excluídos? Ora o termo refere-se às minorias étnicas, ora aos segregados pela cor; por vezes aos desempregados de longa duração, outras vezes aos sem-moradia; em certos casos, aos que fazem opções existenciais contrárias à moral vigente, em outros aos portadores de deficiências, aos aidéticos, aos velhos ou mesmo aos jovens. Excluídos, entre nós, são os desempregados, os subempregados, os trabalhadores do mercado informal, os sem-terra, os moradores de rua, os favelados, os que não têm acesso a saúde, educação, previdência etc., os negros, os índios, as mulheres, os jovens, os velhos, os homossexuais, os alternativos, os portadores de necessidades especiais, enfim, uma relação quase interminável.

Tendo se tornado um conceito de utilização tão disseminada, paga o preço da indefinição. Na verdade, desde que o uso da exclusão começou a se difundir e principalmente agora, quando chegamos a uma situação em que o termo é empregado por quase todo o mundo para designar quase todo o mundo, reveste-se de imprecisão e carece de rigor conceitual.

\section{As imprecisões das abordagens atuais}

Investigando uma parcela da bibliografia mais recente sobre o tema da exclusão, é possível observar desacordo entre alguns autores. Tal divergênciafruto muito mais da falta de tratamento da questão do que propriamente de abordagens conflitantes - evidencia-se em diversos aspectos como a utilização do mesmo conceito na descrição de fenômenos e populações absolutamente distintas, a sustentação de pontos de partida evidentemente inconjugáveis e a busca de propósitos irreconciliáveis entre si. Mesmo no que concerne ao aparecimento do termo - expressão material do conceito - no âmbito das ciências sociais as afirmações não são menos imprecisas, podendo ser 
observados, no mínimo, três posições distintas. Enquanto alguns determinam com precisão o ponto de sua irrupção, outros optam por certa dose de cautela e apontam para sua afirmação recente, sem, no entanto, precisar seu aparecimento; e há ainda aqueles que buscam alertar para o fato de que seu uso, embora menos freqüente do que na atualidade, já se faz presente nas teorizações que em primeiro lugar se ocuparam da compreensão das sociedades modernas em toda sua complexidade.

Um dos mais destacados representantes do primeiro grupo é Jacques Donzelot, autor que, com toda a clareza possível, localiza na França dos anos setenta o aparecimento do termo "exclusão". Segundo ele, esta idéia teria sido introduzida nos escritos relativos às políticas públicas através da denúncia feita por uma obra de René Lenoir quanto aos esquecidos do progresso. Em suas próprias palavras: "Se consideramos a literatura relativa às políticas sociais, $\mathrm{o}$ termo exclusão aparece no começo dos anos setenta com o livro de R. Lenoir que denuncia os esquecidos do progresso: doentes mentais, deficientes, anciãos..." (Donzelot, 1996, p. 88) Do mesmo modo, François-Xavier Merrien, comparando o horizonte dentro do qual o termo é captado na França e nos países anglo-saxônicos, especialmente nos Estados Unidos, não deixa de fazer clara demarcação, senão sobre a data, ao menos sobre o lugar específico de nascimento do termo - a França. Para ele, "se, nos Estados Unidos, o interesse é sobretudo pelos indivíduos, pelos grupos caracterizados por comportamentos desviantes, marginais, ilícitos, na França, onde nasceu o termo exclusão, o interesse é sobretudo pelos processos." (Merrien, 1996, p. 423)

O mesmo Jacques Donzelot, em texto bem anterior ao acima citado (Donzelot, 1991, p. 5 et seq.), já ligara o início da tematização da exclusão social com a obra de René Lenoir, de 1974. Entretanto, o mais interessante deste texto anterior de Donzelot é que ele principia justamente por trabalhar sobre o tema do "deslocamento da questão social" que não apenas será o ponto de partida para toda a sua teorização futura como também reaparecerá, como um quase-pressuposto, num sem-número de estudos posteriores, de diversos outros autores. E penso que esta noção é uma das que está mais fortemente associada ao imbróglio teórico que caracterizou a última década, justamente porque ela mais esconde do que revela o núcleo da questão social. Acompanhemos, pois, por um momento, a linha de pensamento de Donzelot.

A exclusão, ao ser tematizada em 1974, segundo seu ponto de vista, serviu para designar os "esquecidos do progresso". Neste caso, tratava-se simplesmente de uma certa forma de moderar a euforia da sociedade de bemestar e de convocá-la ao alargamento da responsabilidade social. Já no início dos anos 1980, de modo bem diverso daquela omissão involuntária da década anterior, passa a significar uma solução deliberada para a garantia de 
continuidade do modelo social. Nas palavras do próprio Donzelot (1991), para garantir a atualização do sistema "... é preciso reduzir os efetivos, não conservar senão os indivíduos capazes de ajustar-se às mutações tecnológicas e rejeitar os outros, todos os outros." (p. 5) No caso francês, lembra que foi preciso rejeitar, por exemplo, os imigrantes que haviam sido trazidos em massa para ocupar postos de trabalho sem necessidade de qualificação e que agora, pelas exigências da produção, tornavam-se indesejáveis. Dos mesmo modo, os que se mantêm presos a competências ultrapassadas, a regiões desertificadas pela produção, a moradias que embora compradas à custa de enormes sacrifícios perderam todo o valor, todos estes também tiveram que ser descartados. Ainda os que chegam ao mercado de trabalho sem a bagagem escolar indispensável em tempos de rarefação do emprego ou os que, em virtude de handicaps físicos, são impossibilitados de alcançar as performances requeridas, enfim, todos os que acumulam tais desvantagens e que foram designados como "os novos pobres" tiveram que ser postos à parte.

Neste ponto, então, Donzelot dá o pulo-do-gato. Ele extrai como resultante desse processo o surgimento de uma nova linha de clivagem social. A seu ver, esta já não mais divide seus membros no locus da produção, segundo a clássica oposição entre empregador e assalariados. Diferentemente, a linha agora separa as pessoas “... lá onde eles vivem, na cidade, com a discriminação entre os espaços reservados aos engenheiros, aos técnicos e aos escalões superiores e aqueles abandonados às populações sem qualificação. Ela é literalmente deslocada." (Donzelot, 1991, p. 6)

O diagnóstico do ocorrido na sociedade francesa pode estar acertado. Aceitemos em confiança - e por que não fazê-lo? - que a descrição do autor retrate com fidelidade a rejeição desses grupos sociais na França. Entretanto, derivar daí o surgimento de uma nova linha de clivagem, avançar para um "deslocamento da questão social" e, finalmente, fazer disto uma categoria analítica substantiva soa como recurso para esquivar-se com destreza do real problema. O que ocorre aqui é que Donzelot abandona o problema em si e fica apenas com sua manifestação aparente. $\mathrm{Na}$ verdade, não há qualquer "deslocamento" da questão social, muito menos estamos diante de uma nouvelle question sociale. Sucede que a intelligentsia do estado desloca o foco da análise e atrai as atenções para o que aparece à superfície. Deste modo, a atitude mais típica da teoria que gravita em torno do estado de bem-estar é o estabelecimento das corretas políticas compensatórias destinadas a controlar os efeitos do pleno desdobramento da lógica do capital.

O segundo grupo, aquele que reconhece ser a exclusão um conceito recente, sem, no entanto, precisar seu aparecimento, pode ser exemplificado através de diversos autores. Pondo em dúvida a visão estática e a paternidade exclusiva de 
uma pessoa sobre um termo tão difundido como a exclusão, Paugam (1996) chega a nos recordar que o mesmo Lenoir confessou não ter escolhido o título de seu próprio livro - Les Exclus, un Français sur dix. Entretanto, mesmo relativizando a questão, não altera substantivamente a época do aparecimento desta noção. "Será pois em meados dos anos sessenta, em período de prosperidade econômica, que a noção de exclusão faz sua aparição na França." (Paugam, 1996, p. 9) Numa linha semelhante de argumentação, Oliveira (1997) destaca que, embora somente nos últimos anos o termo "excluídos" tenha surgido no cenário público, sua tematização já pode ser observada, entre nós, nas obras de Fernando Henrique Cardoso e Enzo Faletto, Lúcio Kowarick, Alba Zaluar, Hélio Jaguaribe e Cristovam Buarque. Há ainda aqueles que, como Gilberto Dupas, entendem que o surgimento das discussões em torno da exclusão social está associado muito mais a uma complexa conjuntura internacional, contando com a concorrência de múltiplos fatores do que a algum autor específico que em determinado momento tenha forjado tal conceito. Para ele, foi no “.... contexto complexo de globalização e de alteração do papel do estado que surgiu a preocupação com o novo fenômeno que se convencionou chamar exclusão social." (Dupas, 1999, p. 16)

Diante das posições entusiasmadas com a suposta novidade descoberta pelas ciências sociais das últimas décadas, Ferraro (1999) secundariza o problema da criação do termo e mesmo do conceito de "exclusão" para afirmar que fatos realmente novos são a freqüência de seu uso, sua centralidade nas análises e a "ambigüidade do seu conteúdo". Ao retornar aos textos de Marx em busca do significado da exclusão nas áreas do trabalho e poder, sua expectativa é uma só: “... o resgate do uso do termo na obra de Marx talvez possa iluminar o debate atual sobre o significado e o alcance teórico e político do conceito de exclusão." (p. 300) Pelo menos no que diz respeito ao reconhecimento de que o fenômeno da exclusão social não surge no mesmo período em que o termo passa a ser empregado com maior freqüência, outros autores poderiam ser ajuntados aqui, formando um terceiro grupo. É o caso, por exemplo, de Julien Freund que, prefaciando um importante estudo sobre a exclusão, afirma que embora no sentido que vem sendo empregado o termo seja recente, “... o estado que o conceito exprime encontrava-se em numerosas sociedades de outros tempos, sob a forma ... do exílio, do ostracismo ateniense, da proscrição ou do desterro em Roma e noutras partes, da condição de pária na civilização hindu, ou do gueto, desde a Idade Média." (Freund, in Xiberras, 1993, p. 7)

Uma passagem extensiva, ainda que superficial e incompleta, pela bibliografia pertinente conduz-nos, forçosamente, à confirmação da posição de Ferraro (1999). Sem dúvida, vários autores salientam a ambigüidade e confusão conceitual que cercam o problema; mas mais ainda, encontra-se de 
forma expressa a utilização confusa e nem ao menos admitida em textos desses últimos anos. Tomemos apenas alguns exemplos destes casos. Paugam (1996), introduzindo a compilação dos artigos mais recentes, sob a forma de um "estado do saber" sobre o tema da "exclusão", insiste em expressões como “... o caráter equívoco desta noção ...” (p. 7), “... a noção de exclusão permanece equívoca ..." (p. 11); e "Ela [a noção de exclusão] permanece ainda relativamente fluida ..." (p. 16) que confirmam a equivocidade e fluidez desse conceito. Por fim, conclui o organizador que diante de um uso por demais ampliado, em que tal conceito designa as mais diversas situações ou populações, torna-se difícil definir o que há de comum entre elas:

A noção de exclusão, à medida que ela se generaliza, torna-se, de fato, cada vez mais fluida e equívoca como categoria de pensamento científico. Ela é de tal modo banalizada que todo mundo recorre a ela para caracterizar diversas situações ou populações das quais às vezes é bastante difícil perceber o que têm em comum. (Paugam, 1996, p. 17)

Veja-se, entretanto, que a dificuldade conceitual nem sempre é assumida assim com tanta clareza. Há aqueles que chegam mesmo a admitir a utilização do termo exclusão social unicamente como substituto pouco refletido de outros conceitos já mais solidificados na tradição. Por exemplo, Rocha-Coutinho (1995) pode ilustrar perfeitamente esta situação através da seguinte expressão: “... condição de marginalidade ou, para usar um termo mais em voga, exclusão social ...”. (p. 27)

O que mais importa neste caso é justamente a imprecisão com que este conceito adentrou - e hegemonizou - o cenário contemporâneo, fato que vem sendo denunciado por um já significativo número de teóricos. Pedro Demo, por exemplo, não sem uma certa dose de ironia, refere-se à questão do "charme" que representam as teorizações que se utilizam da linguagem do momento e chega a advertir que estamos, atualmente, diante do "... modismo da exclusão social, sobretudo de cariz francês ...”. (Demo, 1998, p. 1) De maneira semelhante, Elimar Pinheiro do Nascimento reconhece e chama a atenção sobre o mesmo problema: "Exclusão é um destes conceitos que a moda, e o abuso decorrente, acabam por decepar o seu vigor. Polissêmico, termina por não servir a quase nada." (Nascimento, 1997, p. 88) E para mostrar ainda mais um exemplo, tomemos também José de Sousa Martins que assevera: "O discurso corrente sobre exclusão é basicamente produto de um equívoco, de uma fetichização, a fetichização conceitual da exclusão, a exclusão transformada numa palavra mágica que explicaria tudo." (Martins, 1997, p. 27) Para ser mais exato, no caso de Martins, o que é mais relevante nesta discussão não é exatamente o modismo ou a imprecisão do conceito; o que ele ataca com maior veemência é “... que o conceito é 'inconceitual', impróprio, e distorce o próprio problema que pretende explicar.” (Martins, 1997, p. 27) 
Também são bastante ilustrativas as posições de Serge Paugam, às quais já foram feitas algumas referências, quando justapostas aos pontos de vista de pesquisadores brasileiros que articulam suas investigações com as do francês. Por conta desta cooperação, Paugam esteve no Brasil em 1998 para uma série de conferências e debates, cujo resultado foi reunido com o objetivo de "... constituir-se em contribuição para a clareza conceitual do alcance e limites da exclusão social entre nós ...". (Véras, 1999, p. 8) No texto preliminar, visando justamente situar o debate da exclusão e da desqualificação social no Brasil, a editora da coletânea já adverte para dois sérios problemas. Em suas palavras:

O termo exclusão acabou por ser algo duplamente interpretado. De um lado, conceito tão amplo, espécie de palavra-mãe (conceito horizonte) que abriga vários significados para reunir pessoas e grupos que são abandonados, desafiliados (Castel), deixados de lado, desqualificados (Paugam) quer do mercado de trabalho quer das políticas sociais, etc. De outro ângulo, é um conceito equivocado, atrasado, desnecessário. (Véras, 1999, p. 14)

E estes são exatamente os problemas que Paugam, em suas conferências, aborda repetidamente. Para ele, embora a noção de exclusão social esteja ocupando lugar central nos debates políticos europeus, “... seu uso é tão variado e impreciso que, freqüentemente, torna-se inconsistente e, às vezes, equivocado." (Paugam, 1999a, p. 49) A imprecisão conceitual associada à variedade de situações que pretende designar retira-lhe qualquer efetividade, reduzindo-a a termo banalizado. Assim, num tipo de situação não muito diferente de experiências que temos tido na política brasileira, Paugam mostra como a exclusão na França encaixa-se como parte de qualquer discurso.

Na França, hoje, impressionantemente, todos os problemas sociais se referem à exclusão. No momento, redige-se uma lei que é pertinente a todos os tipos de exclusão. O tema é tão geral, que nas últimas eleições, todos os candidatos à presidência tinham em suas plataformas de governo, algum documento referente à exclusão. Tanto faz, direita ou esquerda, todos falavam da exclusão. Jacques Chirac, que é de direita, ganhou as eleições falando da exclusão e usando o termo "fratura social". (Paugam, 1999a, p. 52)

A esta imprecisão que, por um lado, permite que o termo seja usado para descrever populações que não têm nada em comum e, por outro, torna-o disponível a intencionalidades bem distintas, soma-se ainda o pavor social de uma luta contra o desconhecido. Talvez por isso, Véras (1999) tenha assinalado que a exclusão faz lembrar, "... pelas controvérsias que suscita, a frase conhecida: No creo en brujas, pero que las hay, las hay." (p. 14) É esta a sensação captada por Paugam (1999c) no povo francês, depois que o estado de bem-estar começou a mostrar seus limites históricos. "Embora não se saiba precisar muito bem e exatamente qual é o conceito de exclusão, muitas pessoas têm medo de se ver nessa situação que um dia poderia atingi-las." (p. 116) De 
outra parte, Aldaíza Sposati, no debate com o sociólogo francês, mostra que a exclusão, como perda de conquistas, pressupõe a universalização de um certo nível de efetivação dos direitos sociais que nunca experimentamos. Por isso, "... no Brasil a exclusão representa uma perda virtual de uma condição nunca antes atingida e não uma perda real capaz de sensibilizar a sociedade." (Sposati, 1999, p. 133)

Enfim, parece não haver uma preocupação muito grande em termos de rigor conceitual. Não é desprovida de razão a advertência pouco otimista de Julien Freund de que "... a noção de excluído está a caminho de sofrer o destino da maior parte dos termos que foram consagrados, nos nossos dias, pela mediocridade dos modos intelectuais e universitários: está saturada de sentidos, de não-sentidos e de contra-sentidos." (In: Xiberras, 1996, p. 12) Se, por um lado, é evidente a falta de clareza em algumas formulações atuais, não se pode deixar de reconhecer o grande esforço teórico que vem sendo empreendido e os inegáveis avanços já obtidos, no sentido de uma afirmação mais precisa do conceito "exclusão". E é justamente no interior deste esforço coletivo que poderão ser encontradas as questões mais candentes na linha de preocupação deste trabalho.

O trabalho de mapeamento do conceito exclusão levado a efeito por Hélène Thomas, embora por demais circunscrito aos debates travados no campo das políticas públicas na França e nos países da Europa Ocidental, pode oferecer algum esclarecimento. Para ela, a idéia da exclusão, que se impôs a partir dos anos 1970, além de pouco a pouco ir substituindo a noção de pobreza, trouxe um novo vocabulário, uma nova forma de análise e um novo tratamento das questões sociais. Além disso, conforme a época que se considere, aparecem como que novas definições da categoria, às quais correspondem formas específicas de designação, certas taxionomias e instrumentos de discriminação. Assim, após percorrer detidamente as diversas lógicas de emergência e estruturação da idéia de exclusão nas últimas décadas do século XX, a autora conclui: "A exclusão não é um conceito sociológico operatório, mas uma categoria semicientífica de conhecimento prático e ação." (Thomas, 1997, p. 195) Assim, trata-se, na verdade, de uma categoria da ação pública relacionada com a assistência social.

Tomemos novamente as reflexões de Paugam (1996) para uma aproximação do cerne da questão. Para este cientista social francês, o sentido da exclusão alterou-se nos últimos anos e hoje não se trata tanto da identificação dos grupos sociais de fato excluídos, senão do processo que conduz à exclusão.

Pode-se, portanto, dizer que a exclusão, tal como doravante a entendemos oficialmente, não tem mais grande coisa a ver com a definição que lhe deram Kanfler nos 
anos sessenta ou Lenoir nos anos setenta. Não se trata mais de designar um ou dois grupos sociais caracterizados por uma exclusão de fato, mas sobretudo de sublinhar a existência de processos que podem conduzir a estas situações extremas. (Paugam, 1996, p. 15)

Além dessa marca de seu entrelaçamento a um processo da própria sociedade que impede a integração de certos grupos, cortando os liames da integração social, outro elemento, aceito ainda mais consensualmente que o acima exposto, deve ser incorporado à determinação do conceito de exclusão: trata-se do ritual simbólico de que se reveste tal fenômeno. Para Castel (1996), este é o traço decisivo para que a noção não seja mais confundida com aquela de marginalização.

A exclusão não é a marginalização, ainda que possa a ela conduzir. Para conferir um mínimo de rigor a este termo, é necessário levar em conta os procedimentos ritualizados que sancionam a exclusão. Eles são muito diversificados, mas remetem a um julgamento pronunciado por uma instância oficial, apoiando-se em regulamentações e mobilizando os corpos constituídos. (Castel, 1996, p. 35)

É desta caracterização dada por Robert Castel que deriva uma problemática paralela e, ao mesmo tempo, decisiva para a abordagem da exclusão, a saber: o estigma. Esta noção de "marca", de "sinal infamante" é a que tem contribuído mais diretamente para que o problema dos excluídos não mais seja circunscrito às relações de classe mas, antes, passe a ser considerado sob uma ótica cultural. Sem pretender mapear integralmente o debate hodierno, deixemos de lado a bela análise levada a cabo por Rocha-Coutinho (1995, p. 29 et seq.), bem como o não menos instigante estudo de Wacquant (1995, p. 68 et seq.) e fixemo-nos em apenas um exemplo que pode ser esclarecedor. Dal Lago (1996) descreve o novo cenário da exclusão argumentando que atualmente ela já não mais se refere aos fracos, pobres, marginalizados... Na verdade, o conceito indica os grupos que ameaçam a convivência e, por isso, são tidos como "alienígenas" ou "inimigos".

Hoje, o termo exclusão não sugere apenas, diferentemente do que ha uma dezena de anos, a existência precária dos assim chamados sujeitos sociais débeis, pobres, idosos ou marginais. Descreve, sobretudo, a condição dos diversos tipos de 'estranhos' ou 'inimigos' que, segundo relevantes setores da opinião pública, ameaçariam a convivência nas metrópoles ricas do mundo: estrangeiros internos e externos nos EUA (a minoria negra, os imigrantes centro-americanos) e estrangeiros externos na Europa de Maastricht, imigrantes em primeiro lugar e depois prófugos e nômades. (Dal Lago, 1996, p. 3)

Embora fazendo uma identificação objetiva dos grupos a que se pode adscrever a caracterização de "excluídos", abre-se na argumentação uma enorme janela, advinda do emprego de termos como "alienígenas", "inimigos". Na verdade, é a uma dupla estigmatização que o autor se refere. De um lado, a 
marca do estranho, do estrangeiro, do diferente, do fora da normalidade convencionada; de outro, o sinal da periculosidade, da ameaça ao estabelecido. Deste modo, o conceito tanto se mostra adequado à descrição dos grupos citados, como é capaz de uma surpreendente elasticidade; tanto pode contribuir para uma mais correta interpretação dos fenômenos sociais contemporâneos, quanto possibilita a dissimulação de sua gênese. Pois é exatamente a isso que se refere Oliveira (1997), caracterizando o problema teórico advindo da falta de rigor conceitual.

Chamar de excluído todo e qualquer grupo social desfavorecido pode levar a contra-sensos, como aplicar um mesmo conceito tanto a moradores de rua quanto a pessoas que, apesar de portadoras de deficiência física, gozam de uma situação econômica bastante confortável [...] Uma confusão desse tipo, independentemente das discussões de natureza política que enseja, é inaceitável porque os processos de exclusão que afetam os dois grupos não têm nada em comum: nem a mesma origem nem a mesma natureza, além de não se manifestarem da mesma maneira e, com toda evidência, demandarem tratamentos bastante diferentes. (p. 50)

Chegamos, assim, ao próprio centro da questão da exclusão em nossos dias. Afinal, é ainda possível manter as categorias próprias do quadro referencial de classes sociais - como o faz Oliveira (1997) -, ou necessitamos uma rede categorial outra, que responda por uma lógica absolutamente outra?

\section{A escola francesa e o novo paradigma}

Nos dias atuais, quando não parece desprovida de senso a advertência dos que dizem que a noção de exclusão tornou-se modismo presente nos mais diversos campos do saber e na opinião corrente do senso comum, por certo os tratamentos dispensados a este conceito também acompanham a tendência e proliferam. Entretanto, a despeito da existência de diferentes concepções, dentre todas ressalta a abordagem que, desde o último quartel do século XX, vem sendo desenvolvida por um amplo setor da sociologia francesa. No caso do debate atual no Brasil, por exemplo, é tão destacada a influência desta escola que, em alguns momentos, ela chega mesmo a aparecer como se fosse a única via de acesso teórico à questão.

A notoriedade alcançada pela teorização francesa pode ser explicada por inumeráveis elementos que se conjugam. Aqui, sem pretender apontar quais deles são os mais relevantes, quero enumerar dois fatores bastante associados entre si.

Em primeiro lugar, conforme já demonstrado no primeiro capítulo, e diferentemente do anunciado por alguns mais afoitos, a criação do conceito exclusão não é obra da sociologia francesa, muito menos é recente. Não é 
menos verdade, entretanto, que foi seu emprego nas reflexões dos franceses preocupados em estabelecer políticas públicas compensatórias do colapso do estado de bem-estar que colocaram o termo na ordem do dia. Deste modo, se não foi criação da década de 1970, é mesmo verdade que a partir desta época coube à sociologia francesa sua popularização. Deste modo, não é por outra razão que os debates atuais sobre a exclusão social reconhecem ser ela “.... tema da atualidade, usado hegemonicamente nas diferentes áreas do conhecimento ..." (Sawaia, 1999, p. 7). Dito de outro modo, em virtude da popularidade que alcançou pela insistência com que foi empregada na sociologia da França, alcançando progressivamente maiores espaços “... na mídia, no discurso político e nos planos governamentais, a noção de exclusão social tornou-se familiar no cotidiano das mais deferentes sociedades." (Belfiore-Wanderley, 1999, p. 16)

Em segundo lugar, e como decorrência natural de ter alcançado fama graças a sua problematização por uma escola especificamente, aqueles que mais recentemente têm tematizado o fenômeno da exclusão social a partir de outras matrizes de compreensão teórica precisam fazer referência à escola francesa, mesmo que na maioria dos casos seja na forma de uma breve menção, antes de construir sua via própria de acesso à questão. Este é o caso, por exemplo, do grupo de pesquisadores ingleses que tem se esforçado em pensar as formas típicas deste fenômeno no Reino Unido, e mais especificamente na Inglaterra. Em coletânea de trabalhos, na qual examinam as respostas em termos das políticas públicas desenvolvidas em seu país e desenvolvem um possível quadro teórico de análise e avaliação das mesmas, pode-se ler: "O termo 'exclusão social' originou-se na política social dos governos socialistas franceses dos anos 1980 e foi usado para fazer referência a um grupo de pessoas absolutamente diferentes, vivendo à margem da sociedade e, em particular, sem acesso ao sistema de seguridade social.” (Percy-Smith, 2000, p. 1) De forma semelhante, a Organização Internacional do Trabalho, mesmo que busque uma caracterização teórica própria sobre a exclusão social, visando distinguir-se da sociologia e da assistência social francesas, precisa ainda considerar: "A identificação dos paradigmas de exclusão pode iniciar apropriadamente com a história do discurso francês da exclusão." (Silver, 1995, p. 63) Ou ainda, no mesmo contexto: "O discurso da exclusão começou a aparecer na França durante os anos 1960.” (p. 63)

A esta forma de tratamento do problema da exclusão social que estamos caracterizando sob a rubrica de "escola francesa" podem ser adscritas certas características que aproximam os diferentes pesquisadores e tornam possível, malgrado as particularidades da reflexão de cada um, identificá-los como grupo que compartilha elementos teóricos comuns. Assim, é possível afirmar inicialmente que o ponto de partida da sociologia francesa é a aceitação de uma 
chamada nouvelle question sociale. Embora nem sempre o termo empregado seja o mesmo e haja, inclusive, discussões sobre a pertinência ou não de seu uso, deve-se considerar que a diferença teórica não chega a ser relevante nos diferentes casos. Mesmo naqueles autores que preferem aludir a um deslocamento da questão social, não resta dúvida que o acento sempre se põe na perspectiva de uma novidade que não mais pode ser apreendida com o recurso às mesmas noções que vinham sendo empregadas em momentos anteriores. Portanto, é mister agora indicar quais as noções que a exclusão social pretende substituir e quais as características, ou as feições inauditas da sociedade que reclamam novas categorias analíticas.

Uma primeira observação precisa ser feita. Não é consenso na escola francesa que a exclusão social esteja necessariamente associada à constituição de um novo paradigma; entretanto, a maioria daqueles que advogam a afirmação desta tese enunciam com precisão o que precisa ser substituído. Ouçamos um de seus representantes: "O paradigma da exclusão tornou-se brutalmente dominante há alguns anos, enquanto o da luta de classes e desigualdades dominou os debates políticos e a reflexão sociológica desde o fim da Segunda Guerra Mundial.” (Schnapper, 1996, p. 23) Mais adiante será preciso voltar à questão do novo paradigma; por ora basta afirmar que o maior consenso está em afirmar que os conceitos que já não servem mais, já não dão conta da situação presente são a marginalização, a pobreza e a desigualdade.É fundamentalmente como resposta à inadequação destas noções que se afirmam tanto a exclusão como outras idéias que gravitam a seu redor, tais como desafiliação, desqualificação etc. Portanto, a tarefa que dá arrancada a esta perspectiva analítica é a explicação de “... como se chega ao ponto de, hoje em dia, quase não se falar de pobreza e, sim, de exclusão. Qual a diferença entre exclusão e pobreza? E assim, também, poder-se-á perguntar qual a diferença entre desigualdade e exclusão ..." (Paugam, 1999a, p. 52)

A razão apontada como determinante para o abandono dos conceitos vinculados ao pauperismo é o limite que estes impõem para a investigação da nova questão social. Tratando-se de conceitos eminentemente quantitativos, trazem duas ordens de problemas. Primeiro, a pobreza é dimensionada em termos de renda e quantificada através de meticulosos estudos estatísticos que definem as linhas de separação entre quem é pobre e quem não é, ou entre os diferentes níveis de pobreza. Ora, na medida em que se devem realizar cálculos complexos que levam em conta fatores tão específicos como, por exemplo, a diferenciação de consumo entre crianças e adultos, resta sempre a incerteza de que a simples alteração de certos parâmetros considerados no cálculo conduziria a conclusões diferentes que não levariam em conta outros aspectos que não os econômicos. “... o número de pobres poderá variar a partir de índices diferentes de cálculos convencionados, levando a concluir que, em 
relação à pobreza, sempre subjaz uma questão social e política. Admite-se uma norma que é aceita, mas que pode sempre ser contestada." (Paugam, 1999a, p. 54) A segunda ordem de problemas que inviabiliza o emprego da noção de pauperismo é, na verdade, outro ângulo de enfoque da dificuldade já descrita, ou seja, limitando-se ao aspecto quantitativo da renda impossibilita o estudo de importantes faces da nova questão social como as ligadas à cultura, à identidade, à subjetividade, às representações.

A segunda resposta que precisa ser buscada, além dos conceitos a serem substituídos, é a das características contemporâneas da sociedade que são apresentadas como a nova questão social. Também neste aspecto não há perfeito consenso entre diferentes autores da escola francesa, entretanto, dois fenômenos parecem ser os principalmente referidos. Primeiro, muitos afirmam - pelo menos ninguém nega explicitamente - que a sociedade contemporânea não pode mais ser compreendida se permanecer a insistência em localizar na produção o foco da questão social. Não nos encontramos mais no tempo da sociedade industrial e, portanto, é preciso deslocar a questão social do campo da produção econômica para o das representações sociais. Segundo, parece mais adequado para o início da era industrial, para o momento da barbárie econômica, antes ainda de se terem consolidado e universalizado as conquistas promovidas pelo estado de bem-estar social, falar-se em pobreza. Entretanto, o novo quadro apresentado nas últimas décadas do século XX é bem diferente. Se é verdade que o espectro de abrangência da noção de exclusão pode abranger todas as formas concretas de pobreza, desde o início do período industrial até os dias de hoje, a sociologia francesa argumenta que é necessário uma atenção específica para as novas formas de pobreza, “... àquelas do período de prosperidade dos anos 1960-1970 e, sobretudo, àquelas da crise que lhes sucederam." (Thomas, 1997, p. 15) Neste novo momento, seja durante a prosperidade, quando a nova pobreza era apenas residual, seja no período de desmontagem do estado de bem-estar, quando se torna acúmulo de deficiências, é mais apropriado o recurso à elasticidade da idéia de exclusão social e suas aparentadas.

Pelo fato de ser colocada nesses termos, este ponto de partida da escola francesa já começa a despertar inquietações relativas à recepção no Brasil desta linha de pensamento. Assim entendida, a exclusão social tem por patamar a eqüidade e a cidadania que foram alcançadas nos países centrais, como a própria França. Então, o entusiasmo pela conceituação de uso mais corrente pode significar o paradoxo de assumirmos um novo jargão das políticas públicas sem termos alcançado jamais assumir os mesmos níveis de compromisso social. $\mathrm{Ou}$, para ficarmos com o alerta de Sposati (1999): “A concepção de exclusão social como perda de uma conquista ... pressupõe a anterior universalidade da cidadania. No caso brasileiro, este patamar de universalidade da cidadania não foi 
ainda consagrado nem na sociedade nem no estado." (p. 131) E antes de passar à exposição de outras características da escola francesa, talvez seja conveniente refletir um pouco mais sobre a nouvelle question sociale, ou seu deslocamento.

[...] pode-se perguntar se se trata de nova questão social, ou apenas de fase posterior do sistema capitalista. Quando se apela para um novo paradigma, a expectativa é de que teria ocorrido mudança radical do sistema, algo difícil de comprovar, já que ainda se trata do mesmo, embora em outra fase, dotada esta de grandes mudanças, as quais implicam reconhecer situações novas, mas não podem empanar o fato de que não saímos do sistema. Mesmo que tais mudanças fossem interpretadas como degeneração do sistema, é sempre possível argumentar que este tipo de exclusão faz parte da dinâmica capitalista de produção. Será útil abrir espaços mais arejados de análise, também para acompanhar um sistema que evolui rápido para conformações surpreendentes. Não cabe continuar analisando o capitalismo com as mesmas categorias de sempre, pois implicaria colocar a realidade a serviço da teoria. Não segue, porém, que exista nova questão social, até porque, com olhos de Terceiro Mundo, é mais fácil ver nela a velha questão social. (Demo, 1998, p. 25)

Uma das marcas caracterizadoras mais evidentes da escola francesa e ponto no qual os diversos autores encontram maior nível de acordo é, com certeza, a questão do liame social. Não é sem razão que este ponto chega mesmo a ser apontado como algo que poderia até aglutinar as diversas formas de compreensão do fenômeno exclusão social.

O ponto comum a estas múltiplas formas de exclusão parece residir na ruptura dos laços que elas acarretam, directamente ou a mais longo termo. Ruptura do laço social, mas também do vínculo simbólico, um e outro ligando, normalmente, cada indivíduo à sua sociedade. Excluído de uma das esferas do social, o actor rompeu, pois, os laços que o retinham perto dos outros actores, mas também perto das representações que lhes eram comuns. (Xiberras, 1993, p. 32)

Serge Paugam, eminente representante da escola francesa e organizador de uma das obras mais completas sobre o tema, na qual juntamente com outros cinqüenta autores oferece um panorama que condensa os pontos de vista desta corrente, esteve há bem poucos anos no Brasil para uma série de conferências e debates com pesquisadores brasileiros. Fruto destas conversações, há um texto cujo título já diz, por si só, a respeito do ponto central da sociologia francesa da exclusão: $O$ enfraquecimento e a ruptura dos vínculos sociais: uma dimensão essencial do processo de desqualificação social. (Paugam, 1999b) O mesmo autor afirma ainda que a própria noção de exclusão, enquanto acúmulo de deficiências, deve ser compreendida através do recurso a esta mesma noção. "Esta é a razão pela qual se pode falar de um processo no qual os vínculos sociais se desfazem, sendo muito comum o exemplo de uma pessoa que perdeu o emprego, passou depois por um processo de divórcio, em seguida perdeu a moradia etc." (Paugam, 1999a, p. 56) Por seu turno, Donzelot (1996) remete as diferenças de concepção sobre a exclusão às diversas formas de compreender a 
solidariedade e o estabelecimento do liame social. Além disso, ao trabalhar sobre os princípios de uma nova metodologia da ação social, retoma as categorias de solidariedade mecânica e solidariedade orgânica e trata da proteção e do auxílio social enquanto formas de reatamento do liame social e, por consequiência, de combate à exclusão. (cf. Donzelot, 1991, p. 16 et seq.) Ainda outro representante destacado da corrente francesa, mesmo que desconfie da serventia do termo exclusão (cf. Castel, 1997a, 16 et seq.), permanece tendo como preocupação básica a coesão social que, segundo ele, deixou de ser alavancada pelo trabalho. "A nova questão social hoje parece ser o questionamento desta função integradora do trabalho na sociedade." (Castel, 1997b, p. 165) Ele mesmo já anteriormente, mesmo que estivesse propondo um outro termo para designar o fenômeno exclusão social, mantivera-se concorde quanto a caracterizá-la como rompimento do laço social. De acordo com sua argumentação, as diferentes modalidades do que se tem chamado exclusão social “... exprimem um modo particular de dissociação do liame social que chamarei 'desafiliação'.” (Castel, 1991, p. 138-139)

Outra característica da linha argumentativa desenvolvida pelos teóricos franceses está ligada à busca de reatamento do laço social mas não se explica unicamente por este fator. Refiro-me à inspiração durkheimiana desta corrente sociológica, claramente assumida, por exemplo, por Serge Paugam. "A idéia que preside numerosos trabalhos orientados pela noção da exclusão, é ... que os vínculos sociais se afrouxam. Esta idéia não é nova. Ela já estava, como se sabe, no centro das preocupações de Durkheim." (Paugam, 1999a, p. 50) Certamente é por esta razão que Paugam inicia o compêndio L'exclusion: l'état des savoirs justamente identificando a exclusão através da referência a conceitos aparentados aos de Émile Durkheim. Para ele, a exclusão, além da precariedade, se faz acompanhar do "... sentimento quase generalizado de uma degradação da coesão social." Continuando, passou a constituir “... o paradigma a partir do qual nossa sociedade toma consciência de si mesma e de suas disfunções ..." (Paugam, 1996, p. 7) Do mesmo modo, para Donzelot (1996) “... o termo exclusão torna-se, assim, a palavra-chave para designar um mal-estar (malaise) social ...” (p. 88)

Visando conferir à expressão de exclusão social uma determinação mais acurada, Serge Paugam afirma ter encontrado nas contribuições dos pesquisadores franceses três dimensões que devem ser agregadas ao conceito, a saber: trajetória, identidade e territórios. (Cf. Paugam 1999, p. 61 et seq. ; p. 118 et seq.) A noção de trajetória chama atenção sobre o caráter processual da exclusão; a idéia de identidade ressalta, simultaneamente, a interiorização do déficit, como identidade negativa, e a estigmatização; o aspecto dos territórios fez introduzir no debate o conceito de relégation, reforçando as dimensões da processualidade, da estigmatização, da crise identitária e da construção de 
identidades negativas.

Por fim, outro traço característico da teorização francesa sobre a exclusão precisa ser destacado. As mais variadas abordagens trazem sempre como foco privilegiado de sua preocupação as políticas sociais compensatórias. $\mathrm{Na}$ verdade, já desde suas primeiras formulações, muitos de seus principais autores são figuras ligadas a -ou mesmo dirigentes destacados de-organismos oficiais da assistência social ou dos órgãos encarregados das políticas sociais públicas do estado francês. Atualmente, pode-se encontrar na literatura pertinente a maioria das análises e exemplos concretos remetendo a programas oficiais de reinserção, tais como: ZEP (zone d'éducation prioritaire), Ccpd (conseil communal de prévention de la délinquance), MLJ (mission locale pour les jeunes), SRA (stage de réinsertion en alternance), PAE (projets d'action éducative), APL (aide personnalisée au logement), CLI (comission locale d'insertion), RMI (revenu minimum d'insertion), ... O objeto central, portanto, da escola francesa são, por um lado, as políticas de assistência social, enquanto mecanismos destinados a refazer o laço social rompido, reconstituindo a coesão social; por outro, as políticas de proteção social, compreendidas como as ações do estado endereçadas a evitar o rompimento do laço social onde este esteja enfraquecido. (Donzelot, 1991, p. 18 et seq.; Paugam, 1999a, p. 57 et seq.; Paugam, 1996, p. 573 et seq.; Castel, 1997a, p. 23 et seq.)

Agora é o momento de voltarmos à questão anteriormente levantada sobre a elevação da exclusão social à qualidade de categoria articuladora de um novo paradigma social. Esta questão, embora seja utilizada no discurso de alguns autores da escola francesa (Paugam, 1996, p. 7 et seq. ; Schnapper, 1996, p. 23), mereceu até hoje muito pouco tratamento teórico direto, parecendo gozar da prerrogativa pouco legítima de instituir-se naturalmente.

A tese da constituição de um novo paradigma, que se anteponha àquele das classes sociais, em razão da profunda alteração do modelo de sociedade que temos, comparada com aquela do século XIX, tem em Alain Touraine seu expoente máximo. Sua posição começou a ser construída e conhecida por nós ainda no final da década de 1980 em artigo onde analisava o papel dos chamados novos movimentos sociais e afirmava que na atual sociedade pósindustrial já não faz mais sentido falar-se em classes sociais e muito menos pensar capitalistas e operários como adversários. Para ele, a imagem contemporânea é outra: “... é a de um aparelho central impessoal e integrador, que mantém sob seu controle, além de uma 'classe de serviço', uma maioria silenciosa que projeta à sua volta um certo número de minorias excluídas, fechadas, subprivilegiadas ou até mesmo negadas." (Touraine, 1989, p. 14)

Antes, porém, de investigar objetivamente a posição de Touraine, é necessário desfazer um pequeno e grave equívoco gerado por um de seus 
comentaristas: Jean Baptiste de Foucauld. Buscando inventariar e posicionar-se diante das diferentes concepções teóricas que visam apanhar o fenômeno da exclusão, Foucauld (1992) advoga a existência simultânea dos fenômenos da desigualdade e da exclusão nas sociedades atuais e levanta a pergunta pela natureza desses fenômenos; então, passa a apresentar as teses desenvolvidas face ao problema. Na explicitação de sua própria posição, argumenta que a primeira tese é aquela que considera a exclusão como uma forma extrema de desigualdade. Deste modo, continua Foucauld, não há ruptura, mas um continuит entre os integrados, os precarizados e os desintegrados, o que requer um tratamento dinâmico da questão da exclusão, em que o acento principal não será tanto sobre a descrição do fenômeno consumado, senão sobre os processos que a ele conduzem; não tanto sobre as ações de reinclusão, mas sobre sua prevenção; enfim, pode-se complementar, a exclusão não é tanto um fenômeno conjuntural, mas antes, estrutural. A segunda tese, entretanto, contrapõe-se a esta. É aquela defendida por Alain Touraine, que afirma que desigualdade e exclusão não têm nada em comum por responderem a lógicas distintas de sociedade. A primeira está relacionada à sociedade de produção, à modernidade e à conjugação entre ator e sistema; a segunda tem a ver com o progresso da sociedade de mercado, com a modernização e com a disjunção entre ator e sistema.

Desigualdades e exclusões são ou não da mesma natureza? Nossa sociedade, contrariamente ao que acontecia até 1973, é caracterizada pela simultaneidade dos dois fenômenos: o das desigualdades e o da exclusão. Diante dessa dupla constatação, duas teses se desenvolvem. Em primeiro lugar, a que analisa a exclusão como uma forma extrema de desigualdade, defendida, cada um à sua maneira, por Robert Castel e Étienne Balibar. [...]

A essa abordagem, opõe-se a de Alain Touraine, segundo a qual os dois problemas nada têm a ver, pois a desigualdade e a exclusão respondem a duas lógicas de sociedades, mesmo que estejam superpostas. A problemática desigualitária equivale ao que Touraine chama a sociedade de produção, marcada pela racionalização, pela modernidade e pela boa conjunção entre o ator e o sistema. A problemática da exclusão está ligada ao progresso da sociedade de mercado, caracterizada pela mudança, pela estratégia, pela modernização. Nessa situação, um divórcio crescente aparece entre as demandas sociais e a organização, ou ainda, entre o ator e o sistema. (Foucauld, 1992, p. 47-48)

O problema com esta descrição de Foucauld é que ele faz um adendo mesmo que estejam superpostas - que, no meu modo de ver, altera substancialmente o pensamento de Touraine.

Ponhamo-nos, pois, diante de um artigo do próprio Alain Touraine, publicado no mesmo periódico, um ano e meio antes do aparecimento daquele de Foucauld. A estratégia da argumentação de Touraine (1991) se dá a 
conhecer já pelo título de uma das seções de seu escrito - Du vertical à l'horizontal. Como se pode perceber, trata-se da passagem de um modelo a outro, do abandono de uma perspectiva de análise em favor de outra; trata-se, na verdade, de passado e presente. Portanto, julgo que Foucauld injeta na perspectiva analisada uma idéia contrária à que o autor quer dar. A sinalização da existência superposta dos dois modelos não faz plenamente justiça ao ponto de vista que Touraine pretende defender. Em verdade, seu argumento parte da afirmação de que vivemos um momento de passagem e junta a isso a qualificação da passagem: do modelo vertical ao horizontal, do up/down ao in/out, do paradigma de classe ao paradigma centro/periferia. Concluindo, Touraine adverte que já não há mais um modelo alternativo de sociedade, capaz de a tudo revolucionar.

Nós vivemos, neste momento, a passagem de uma sociedade vertical, a que nos habituamos chamar uma sociedade de classes, com pessoas em cima e pessoas embaixo, para uma sociedade horizontal, onde o importante é saber se se está no centro ou na periferia. Outrora, as pessoas debaixo estavam profundamente persuadidas de que podiam reverter a sociedade em nome de um outro modelo, como dizem ainda os últimos detentores desse discurso, os alternativos. Se se propunha ainda ontem uma outra sociedade qualificada como anarquista, socialista, comunista, a questão não é hoje de ser up or down mas in or out: os que não são in querem sê-lo; de outro modo, eles estão no vazio social. Não há mais modelo alternativo, aquele que tudo revoluciona (bouleverse). (Touraine, 1991, p. 8)

Aqui, é preciso que nos detenhamos um pouco. Em primeiro lugar, “... a passagem de uma sociedade ... para uma sociedade ..." não pode deixar margem a qualquer dúvida e dispensa novos comentários. Em segundo lugar, não é mais o modelo vertical, de classes, o que melhor pode descrever esta nova configuração social. Agora, encontramo-nos diante de um esquema horizontal, dentro/fora, incluído/excluído. Tomemos a sério o novo modelo. Abandonemos por um momento o pólo dos excluídos. Os "in" estão "in what"? Juntamente com o velho modelo, também a busca de entendimento da configuração interna da esfera do centro deve ser posta à margem? Já devemos dar como definitiva a igualdade (ou desigualdade?) dos incluídos? Ou sequer devemos levantar a pergunta pelas desigualdades? Em terceiro lugar, atentemos para a astúcia da expressão "... as pessoas debaixo estavam profundamente persuadidas ...". A carga semântica sobre o termo "persuadir", ainda mais quando empregado na voz passiva, não é desprezível, em absoluto. A associação a significados como "levar a crer", "levar a aceitar", "convencer", "induzir" e "obrigar a convencer-se" veladamente imputa coação aos teóricos que têm na categoria "classe social" um importante instrumento analítico, além de redirecionar contra seus próprios autores o arsenal da "ideologia". Trata-se, assim, não só da pura e simples afirmação de um novo modelo, mas uma afirmação em radical oposição a um outro. Em quarto lugar, é preciso 
reconhecer a mesma astúcia e mordacidade na expressão “... os últimos detentores desse discurso ...”. Enfim, para que não reste qualquer dúvida quanto à posição de Touraine, repitamos, recordando sua crença: "Não há mais modelo alternativo, aquele que tudo revoluciona."

Este novo modo de olhar a sociedade proposto por Touraine, estribado em categorias que fazem referência tão-somente a relações horizontais do tipo in/out, incluído/excluído, tem desdobramentos importantes e, tal qual um novo paradigma que se vai constituindo, aponta para novas ações tidas como válidas, em oposição às que no modelo anterior eram julgadas adequadas. Analisando o caso específico da situação atualmente dominante na França, o autor constata que as populações marginalizadas são empurradas culturalmente em direção ao centro, onde são socialmente rejeitadas. Deste modo, configura-se uma situação de assimilação cultural associada a não-integração social. Diante desta situação, Touraine preocupa-se com o rumo que ela irá tomar e aponta para o perigo de que se transforme em simultaneidade de não-assimilação cultural e não-integração social, determinando-se o que ele chama de um processo de "guetização". Entretanto, há uma outra possibilidade - a de que a assimilação cultural possa acionar a integração social. Para que se possam encaminhar, porém, as ações capazes de estancar a ameaça do gueto, é preciso identificar os fatores que engendrariam cada uma das situações possíveis. Assim, antes de mais nada, é fundamental que seja evitado qualquer engano quanto à natureza do problema - não se trata de um problema social e não serão, portanto, as ações do tipo sindical, como as que tiveram importante papel na sociedade de produção, que o resolverão.

[...] quais são os fatores que conduzem ao gueto, e quais os que conduzirão a uma mistura de integração social e de assimilação cultural? É preciso, então, não se enganar: esse problema não é um problema social, não são as medidas sociais que poderão regulá-lo, não é a uma ação de tipo sindical que é preciso, hoje, recorrer, embora ela tenha desempenhado um papel considerável na sociedade de produção. (Touraine, 1991, p. 9)

Um segundo fenômeno típico, identificado a partir da realidade francesa, é a demanda por uma democracia local, ou seja, a possibilidade de resolver localmente os problemas locais. Diante de tal anseio, Touraine interroga-se sobre as razões que praticamente impossibilitam que ele seja satisfeito. Em primeiro lugar, porque a idéia de bem está fortemente associada à de centro, de Razão, de Universal... Em segundo lugar, porque as mobilizações sociais estão subordinadas às formas de organização derivadas do modelo de classes característico da sociedade de produção. Deste modo, embora admitindo que já possam ser observados progressos neste sentido, reconhece que a associação desses fatores torna-os obstáculos quase intransponíveis para a concretização da democracia local. 
[...] uma é a idéia de que o bem só pode vir do centro e o mal, da periferia; que o centro representa a Razão, o Universal (a escola, o estado etc.), enquanto que a periferia (os habitantes, as pessoas, as empresas, os interesses, as profissões) exprime unicamente o interesse. [...] A segunda razão está ligada a que a mobilização social faz-se segundo as linhas da sociedade de produção: os empresários, os assalariados, os docentes etc. (Touraine, 1991, p. 10)

Retomemos os dois pressupostos para a orientação de ações que possibilitem reverter o iminente risco de guetização - o deslocamento do problema do campo social para o político e a superação das idéias de exaltação do centro e da mobilização a partir dos grupamentos típicos da sociedade de produção. Nestes princípios revelam-se, do modo mais concentrado possível, todos os elementos constituintes da posição de Alain Touraine. No quadro mais geral, sua crítica centra-se sobre a racionalidade iluminista, a partir de um viés pós-moderno; no âmbito mais específico, repudia os modelos analíticos que buscam uma compreensão ampla da sociedade e que não tomam como natural e definitiva a estrutura social ora vigente. Mais especificamente ainda, sua proposta é de contraposição ao modelo de classes e às mobilizações via movimentos sociais no campo das relações produtivas, privilegiando, ao contrário, as estratégias políticas de integração dos excluídos, sem mais.

Digo isso, eu que sou sociólogo de profissão, e que, além do mais, tenho uma preferência manifesta pelos movimentos propriamente sociais. Não é seu tempo. Não estamos mais numa época de movimentos sociais: nós estivemos nela, nós o estaremos amanhã e estou pronto a dizer quais e como, mas, no momento, não é aí que se joga. A vida das sociedades é largamente feita de alternâncias entre os problemas de conflito interno e os problemas, ao contrário, de integração e de exclusão. O problema de hoje não é a exploração, mas a exclusão; por conseqüência, o problema concreto é de criar os instrumentos e as formas de ação política que permitam uma integração social, antes que seja demasiado tarde e que nós entremos no modelo americano pelos seus piores lados, isto é, a segregação e a guetização. (Touraine, 1991, p. 13)

Enfim, revela-se a questão em toda sua transparência: a exploração não é mais problema. Impossível, porém, não ver que ela existe, nem é isto que Touraine afirma; ele apenas indica não ser este o problema. $\mathrm{O}$ eminente pensador francês nem sequer levanta a suspeita de que a integração social tão almejada possa ser uma forma de inclusão subordinada.

\section{O lugar da exclusão numa teoria abrangente}

Com base nos elementos até aqui apresentados, haverá de ser possível a construção de um referencial teórico que possa fundar mais solidamente as investigações educacionais relacionadas ao fenômeno da exclusão. A síntese 
teórica que este trabalho ambiciona apresentar como sua contribuição funda-se na filosofia social marxiana e busca situar a exclusão no contexto de uma teoria abrangente.

No caso das ciências do homem, em geral, e das ciências da educação, em particular, penso não ser mais possível abrir mão do refinado rigor metodológico que nos oferece a abordagem analítico-sintética da dialética de Marx. Assim, a compreensão do concreto, totalidade síntese de múltiplas determinações, reclama a mediação teórica de uma categoria sintética imanente à própria realidade. Ora, enquanto vivemos em formações sociais em que é dominante o modo de produção capitalista, é o capital a categoria que opera a síntese social. Deste modo, no processo de determinação das realidades designadas pelo conceito exclusão, serão as categorias imanentes à rede categorial do capital que deverão ser trabalhadas; o sistema político e as representações simbólicas só têm lugar no sistema se estão submetidos às relações econômicas. Por isso mesmo, sem afrontar a lógica do sistema do capital, só temos conseguido operar com o conceito exclusão colocando como horizonte a inclusão. Mas isto não é mais do que a negação imediata, que apenas reafirma a afirmação pois, em termos práticos, a inclusão do excluído é sua integração à lógica do princípio sintético, à lógica do capital. Em suma, é a negação da negação que precisa ser construída, como alternativa teóricoprática capaz de compreender e superar a exclusão e a inclusão. Somente no interior desta compreensão mais ampla é que pode ter valor analítico o conceito exclusão. Se tal empreitada fosse irrealizável, ter-se-ia que admitir a absoluta imprestabilidade para as ciências da educação dessa categoria tão disseminada em nosso meio. Penso, entretanto, ser possível encontrar um referencial teórico consistente, capaz de amparar com maior solidez as ações educacionais relacionadas ao fenômeno da exclusão, então colocada num sistema complexo de múltiplas e mútuas determinações.

O primeiro passo, portanto, será admitir que a exclusão não consubstancia um universo conceitual apto a constituir um novo paradigma social. Uma categoria que reúna e dê consistência a toda uma gama de conceitos que se articulam ao seu redor e que possa, portanto, assumir o papel de categoriachave de um paradigma de análise e intervenção social, precisa, necessariamente, brotar da própria constituição mais íntima do sistema que pretende explicar. Ora, não é exatamente este o caso da exclusão social em relação às sociedades contemporâneas. Como já foi possível observar, $a$ exclusão está incluída na lógica do capital. E no limiar do novo milênio ainda persiste, mutatis mutandis, o sistema do capital, ou seja, uma rede complexa, de relações multiplamente determinadas, que se articulam como sistema coerido pela lógica do capital. Inumeráveis acontecimentos, fatos, fenômenos que, à primeira vista, parecem absolutamente independentes, formam, na 
verdade, um sistema cuja coesão é garantida pelo princípio do capital. Este poder absoluto submete todos e cada elemento da vida social à sua lógica onímoda e oniparente e, então, refere cada realidade elementar a todas as demais, num sistema reticular complexo.

O sistema do capital é muito mais amplo que o modelo econômico capitalista; atravessa, na verdade, todos os âmbitos de relações que os seres humanos estabelecem. Na sua vida em sociedade, os homens entram em diferentes modalidades de relações que, embora associando-se intimamente uma às outras, são de ordens diversas. Deste modo, é possível identificar três universos distintos de relações: o das relações econômico-produtivas, onde os homens, através do trabalho, estabelecem um processo simbiôntico com a natureza; o das relações político-sociais, ou seja, aquele em que os homens estabelecem entre si processos mediatizados pelo poder; e o das relações simbólico-culturais, onde os homens produzem e reproduzem conhecimento e valoração, num processo de significação da subjetividade. (Severino, 1994, p. 46 et seq.) Estes âmbitos de relações, embora devam ser diferenciados, não podem ser separados. Portanto, “.... enquanto múltiplas mediações, diversidades de uma unidade, interagem de tal modo que qualquer atividade concreta humana, embora podendo ser classificada enquanto incidindo mais especificamente sobre algum desses três registros, de fato, reflete-se sobre a totalidade das relações." (Oliveira, 2000, p. 186)

Nas sociedades contemporâneas, em cada um desses âmbitos, encontramos formas múltiplas de opressões, sujeitamentos, estigmatizações, expurgos de determinados contextos etc., os quais passaram a ser reunidos sob a rubrica da exclusão. Isto não configura, entretanto, uma nouvelle question sociale. Ainda que algumas dessas formas não fossem conhecidas em momentos anteriores, ou melhor, ainda que não despertassem a atenção que passaram a merecer em nossos dias, isso não configura uma alteração substantiva do sistema do capital, marcado, ontem como hoje, pela exploração e degradação no âmbito das relações econômico-produtivas, pela dominação e opressão no âmbito das relações político-sociais e pela indiferenciação e alienação no âmbito das relações simbólico-culturais. Não estamos, portanto, diante de qualquer novidade substantiva que requeira um novo paradigma; nem o pretensamente "novo" paradigma da exclusão - de inspiração durkheimiana - é tão novo assim!

O segundo passo que precisa ser dado vai no sentido da compreensão da exclusão no quadro da articulação dialética entre aparência e essência. As reflexões feitas na primeira parte deste trabalho já são suficientes para determinar o modo de interação entre o conceito exclusão e a lógica do capital; entretanto, é conveniente recolocar aquela mesma argumentação sob um outro 
modo de apresentação. A fim de situar adequadamente o problema da exclusão é mister trazer à discussão, de modo mais explícito, a tensão entre essência e aparência ou, em outros termos, entre fenômeno e coisa-em-si, forma imediata e forma mediata, forma de aparência e nexo interno. É esta tensão que está presente e atravessa toda a forma de exposição de $O$ Capital. O próprio Marx, em carta a Engels datada de 27 de junho de 1867, três meses, portanto, antes de dar a lume o primeiro volume de sua obra máxima, explica ao amigo o que ainda ficará reservado para os volumes seguintes:

Aqui se evidenciará de onde provém o modo de representação dos pequenoburgueses e dos economistas vulgares, a saber, porque no cérebro deles só o que sempre se reflete é a forma de aparência imediata das relações, não o nexo interno destas. Aliás, se fosse este último caso, para que, então, seria necessário uma ciência? (MEW 31, p. 313)

Para que se possa conhecer adequadamente uma sociedade é necessário um certo esforço; isto, porém, ainda não é suficiente. Enquanto seres humanos histórico-sociais concretos não nos colocamos diante de qualquer fenômeno como meras abstrações cognoscentes; quando nos defrontamos com um objeto de conhecimento, estamos, desde sempre, inseridos, com ele, num universo de relações. $\mathrm{Na}$ verdade, sequer podemos supor a atitude objetivista de nos postarmos "ante" o objeto; desde sempre, somos parte do próprio objeto, não o olhamos de fora, mas de dentro. Assim, como seres da práxis, vivemos mergulhados constantemente no mundo das relações econômico-produtivas, político-sociais e simbólico-culturais. Neste tríplice universo, o que se manifesta imediatamente nas relações diretas que se estabelecem é unicamente a forma de aparecimento (Erscheinungsform) do real. Marx já adverte que "... somente a aparência das relações de produção se reflete no cérebro capitalista." (Marx, 1983-1985, v. I/2, p. 138; MEW 23, p. 572) É claro, sua prioridade era a crítica da economia política burguesa, que dava como naturais as relações do sistema do capital. Por isto, insistia em denunciar esta economia vulgar que não ultrapassava o aparecer imediato. No entanto, não desconhece que, em qualquer situação, a forma de aparecimento fixa-se espontaneamente ao pensamento corrente, enquanto o fundo oculto da realidade precisa ser descoberto.

De resto, vale para a forma de manifestação [Erscheinungsform, no original] "valor e preço de trabalho" ou "salário", em contraste com a relação essencial, que aparece, o valor e o preço da força de trabalho, o mesmo que para todas as formas de manifestação [Erscheinungsformen, no original] e seu fundo oculto. As primeiras reproduzem-se direta e espontaneamente como formas comuns e correntes de pensamento; o segundo tem de ser antes descoberto pela ciência. (Marx, 1983-1985, v. I/2, p. 131-132; MEW 23, p. 564)

No mundo das experiências cotidianas, no fluxo diário da percepção 
sincrética e imediata da realidade social, as formas fenomênicas que se reproduzem em nossas mentes, enquanto realizamos determinadas práxis históricas, não correspondem, portanto, ao que as coisas, em seu fundo oculto, são de verdade. O mais desconcertante, porém, é que não se trata apenas de falta de sintonia, senão de um aparecer invertido que confunde-nos a percepção. Enxergamos o Sol como uma pequena esfera, mas não temos dúvidas quanto a sua imensidão; não percebemos os movimentos da Terra, mas sabemo-la em constante fluxo. Mas quando se trata de compreender a sociedade em que estamos inseridos, freqüentemente é aceito como verdade definitiva o aparecer invertido. Que na aparência as coisas se apresentam freqüentemente invertidas, é conhecido em quase todas as ciências, exceto na Economia Política. (Marx, 1983-1985, v. I/2, p. 128; MEW 23, p. 559)

A maioria dos discursos sobre a exclusão social captura exatamente o que não está acontecendo. Em termos gerais ou como concepção teórica abrangente, já foi suficientemente demonstrado que não existe propriamente exclusão - que a exclusão está incluída na lógica do capital. No entanto, mesmo em se tratando de contextos específicos, por vezes a exclusão social é usada para designar formas mais atualizadas de exploração, em outras ocasiões, refere-se à subordinação política; há momentos em que significa segregação, enclausuramento, separação, proteção providencial; noutros, tem a ver com estigmatização. De qualquer modo, trata-se ainda de espoliações, esbulhos, repressões, sofreamentos, restrições, limitações, constrangimentos ... Só mesmo pela reflexão sistemática, por um acesso filosófico mediatizado, que no linguajar marxiano é identificado como ciência, é possível superar esta aparência visível invertida. Isto, porém, supõe uma intencionalidade do sujeito social, sem o que as conexões íntimas do real jamais poderão ser desnudadas.

$\mathrm{Se}$, como o leitor certamente reconheceu por seu próprio sofrimento, a análise das reais conexões íntimas do processo de produção capitalista é uma coisa muito complicada e um trabalho muito circunstanciado; se é uma tarefa da ciência reduzir o movimento visível e apenas aparente ao movimento real interno, então é evidente que nas cabeças dos agentes capitalistas da produção e da circulação têm de se constituir representações sobre as leis da produção que divergem completamente dessas leis e que são apenas a expressão consciente do movimento aparente. (Marx, 1983-1985, v. III/1, p. 234; MEW 25, p. 325)

Dois passos importantes foram dados: primeiro, mostrou-se que o conceito de exclusão não é capaz de consubstanciar um novo paradigma social; segundo, que se trata da forma de aparecimento contemporânea da lógica interna do sistema do capital. Agora, será necessário ir adiante e investigar as relações entre a forma de aparecimento e o movimento interno da realidade. Quando nos deparamos com a célebre afirmação de Marx de que "... toda a ciência seria supérflua se a forma de manifestação [Erscheinungsform, no 
original] e a essência das coisas coincidissem imediatamente ..." (Marx, 19831985, v. III/2, p. 271; MEW 25, p. 825), somos tentados a subestimar o aparecer imediato, excluindo-o in limine da argumentação. Tal procedimento, entretanto, conduz diretamente aos esquematismos e às diferentes formas de sistematizações doutrinárias, uma vez que, não podendo alcançar diretamente o fundo oculto da realidade, o aparecer simples imediato é fixado como forma definitiva do real. Na verdade, embora o fenômeno seja uma manifestação parcial, inadequada ou até invertida da coisa-em-si, ainda assim, é sua única forma de aparecimento. Portanto, como ensinou Hegel na Ciência da Lógica, “... a partir do ser imediato o saber vai para o interior, acha a essência através desta mediação.” (Hegel, 1974, p. 339) Conforme já tivemos oportunidade de observar, Marx inicia $O$ Capital pelo aparecer mais direto e imediato e, a partir daí, penetra em seu interior, a fim de expor seu fundo oculto. Assim, a aparência, ao mesmo tempo em que é enganadora e esconde a essência, é o caminho da sua desocultação. A essência, enquanto forma mediata, manifestase sempre em algo diferente daquilo que ela é. Manifestar a essência é a atividade da aparência. Em suma, o verdadeiro conhecimento não é destruição da aparência, mas de sua pretensão de passar-se por núcleo essencial da realidade.

As três idéias aqui expostas são suficientes para que se compreenda o lugar do conceito de exclusão no interior de uma rede reflexionante abrangente e complexa. A fim de amparar mais solidamente as práxis educacionais - como de resto qualquer outra práxis social - relacionadas com a exclusão, oferecendo-lhes um referencial teórico consistente, é preciso identificar claramente o alcance e os limites do conceito exclusão. Dito de outro modo, é necessário esclarecer os diferentes papéis teóricos que este conceito é capaz de cumprir, e sob quais condições pode fazê-lo.

A vocação mais clara da idéia de exclusão é funcionar como conceito descritivo. Dentre as operações teórico-práticas do processo humano de conhecimento, o nível da descrição das formas de aparecimento imediato da lógica interna do sistema do capital é onde o conceito de exclusão encontra seu emprego mais adequado. No âmbito econômico-produtivo, o estágio mais evoluído das forças produtivas, aliado a modelos mais sofisticados de gerenciamento da produção, gera novas formas de desemprego, mais massivos e de longa duração, que podem ser descritas como formas peculiares de exclusão do mercado de trabalho. Do mesmo modo, o fenótipo contemporâneo da pobreza, as formas refinadas de "descontratualização" do trabalho, bem assim as inumeráveis variações dos modos atuais de exploração e até mesmo o não-acesso à propriedade da terra ou da moradia podem ser muito apropriadamente descritas como formas de exclusão e inclusão forçada. (Fontes, 1997) Na esfera das relações político-sociais, todas as modalidades de 
não acesso aos serviços de saúde, educação, previdência, habitação, amparo legal etc. podem ser descritas como aspectos, singulares ou acumulados, de exclusão dos direitos de cidadania. Por fim, no universo das representações simbólico-culturais, todos os fenômenos que envolvem discriminações, afastamentos do convívio social, estigmatizações, bem como todos os modos de negação do acesso à cultura e ao saber sistematizado, podem, também, ser descritos como exclusões de determinados contextos de valoração e conhecimento. De qualquer modo, importa reconhecer que quaisquer fenômenos do tipo dos precedentes não significam, propriamente, exclusão absoluta, exclusão do sistema enquanto tal. Na verdade, trata-se, isto sim, da descrição de formas imediatas de aparecimento, que precisam ser compreendidas como manifestação invertida da lógica imanente do sistema do capital que é de inclusão subordinada.

Ultrapassado este primeiro nível teórico, o conceito exclusão torna-se cada vez mais dependente da rede reflexionante ampla e pode referir-se unicamente a realidades setoriais. Como conceito interpretativo, estas características já se confirmam completamente. Em primeiro lugar, é preciso voltar a insistir na exclusão como forma de aparecimento de um sistema cuja essência só pode ser explicada com recurso a um referencial complexo. Assim, desde que seja claramente definido e situado no contexto da rede reflexionante toda, o conceito exclusão pode ser útil na interpretação de certos aspectos da realidade social. Destarte, é possível compreender muito mais profundamente o fenômeno do analfabetismo quando o interpretamos como produção social de um modelo escolar regido pela lógica da exclusão. Entretanto, se a exclusão for retirada da rede categorial ampla e tomada como conceito interpretativo independente, há sérios riscos de se explicar a realidade social exatamente como ela não é. Por exemplo, numa primeira hipótese, se for perdido de vista que o limite interpretativo da exclusão são as realidades parciais claramente localizadas, arrisca-se enveredar pelo caminho indutivo das ciências empíricas da natureza e do método científico experimental, o que é absolutamente inadequado em termos de compreensão da realidade social. Assim, como o sistema manifesta-se num modelo escolar regido pela lógica da exclusão, em mecanismos de proteção social governados pela mesma lógica, em sistemas de desenvolvimento científico-tecnológico, de difusão da cultura, de valoração de significados etc., todos excludentes, conclui-se que a exclusão deve ser generalizada como categoria de interpretação da realidade social em geral, constituindo um novo paradigma. Noutra hipótese igualmente pouco construtiva, o pensamento contenta-se em permanecer nas realidades parciais, nos regionalismos, no caos da infinita pluralidade de microuniversos não relacionados entre si, dentro de cada qual, separadamente, faz pleno sentido a exclusão como conceito interpretativo. Neste caso, o pensamento recolhe-se, 
resigna-se, admite sua incapacidade de expor as conexões íntimas, os nexos mediatos, o fundo oculto do sistema do capital. Assim, num regresso para aquém de Kant, a coisa-em-si é declarada inexistente e impensável; decreta-se que o sistema do capital é mera ficção imaginada. Tudo que ultrapassa o mundo fenomênico é "meta-alguma-coisa".

Por fim, pode-se ainda pensar na exclusão como conceito operativo. Este é um dos contextos em que mais frequientemente se encontram suas aplicações. No entanto, é também onde é mais utilizado como conceito independente e, portanto, incapaz de ir além do nível das negações imediatas. O campo das políticas sociais compensatórias é o terreno do planejamento e execução das ações públicas de combate à exclusão. Neste sentido, seu par de oposição é, invariavelmente, a inclusão. Em alguns casos, como projeto intencionalmente deliberado, noutros, por insuficiência teórica, é sempre a própria lógica do sistema que é reposta. Ao construir a negação indeterminada das formas de aparecimento invertido, resulta reafirmada a lógica de fundo do sistema. O que ocorre neste caso é, novamente, que a tomada da exclusão como conceito independente do referencial teórico abrangente faz com que fenômeno e essência sejam percebidos como coincidentes. Deste modo, as formas imediatas de exclusão são compreendidas como quadros patológicos de disfuncio-nalidade. É esta a perspectiva da maioria das políticas de institucionalização da sociedade civil, dos apelos à cidadania, das políticas inclusivas, da educação inclusiva etc. No nível da conceituação operativa, é preciso superar dialeticamente as antinomias - in/out; establishment/outsiders; exclusão/ inclusão - e instaurar práxis histórico-sociais de negação da negação. Em muitas ocasiões, então, será a luta pelo reconhecimento, e não pela inclusão, o caminho desta construção. De qualquer modo, a negação determinada só é possível como contraposição à lógica interna do sistema do capital, a qual rege tanto o aparecer imediato quanto sua negação direta. Dito de outro modo, a construção da negação da negação só pode vir pela recuperação do espaço da exclusão, pela valorização justamente das realidades que, por não se submeterem à lógica do capital, podem oferecer-lhe resistência.

\section{Referências}

BELFIORE-WANDERLEY, Mariangela. Refletindo sobre a noção de exclusão. In: SAWAIA, Bader (Org.). As artimanhas da exclusão: análise psicossocial e ética da desigualdade social. Petrópolis: Vozes, 1999. p. 16-26. 
CASTEL, Robert. As armadilhas da exclusão. In: BELFIORE-WANDERLEY, Mariangela; BÓGUS, Lucia; YAZBEK, Maria Carmelita. Desigualdade e a questão social. São Paulo: Educ, 1997a. p. 15-48.

- As transformações da questão social. In: BELFIORE-WANDERLEY, Mariangela; BÓGUS, Lucia; YAZBEK, Maria Carmelita. Desigualdade e a questão social. São Paulo: Educ, 1997b. p. 161-190.

—_. De l'indigence à l'exclusion, la désaffiliation: précarité du travail et vulnérabilité relationnelle. In: DONZELOT, Jacques (Org.). Face à l'exclusion: le modèle français. Paris: Éditions Esprit, 1991. p. 137-168.

—. Les marginaux dans l'histoire. In: PAUGAM, Serge (Org.). L'exclusion, l'état des savoirs. Paris: Éditions La Découverte, 1996. p. 32-41.

DAL LAGO, Alessandro. Dentro/fuori. Scenari dell'esclusione. aut aut, Milano n. 275, p. 3-7, set.-ott. 1996.

DEMO, Pedro. Charme da exclusão social. Campinas: Autores Associados, 1998. 125 p. (Coleção polêmicas do nosso tempo; 61).

DONZELOT, Jacques (Org.). Face à l'exclusion: le modèle français. Paris: Éditions Esprit, 1991. 223 p. (Série Société).

- Les transformations de l'intervention sociale face à l'exclusion. In: PAUGAM, Serge (Org.). L'exclusion, l'état des savoirs. Paris: Éditions La Découverte, 1996. p. 88-100.

DUPAS, Gilberto. Economia global e exclusão social: pobreza, emprego, estado e o futuro do capitalismo. São Paulo: Paz e Terra, 1999. 219 p.

FERRARO, Alceu R. Exclusão, trabalho e poder em Marx. Sociologias, Porto Alegre, v. 1, n. 1, p. 300-325, jan.-jun. 1999.

FOUCAULD, Jean Baptiste de. Exclusion, inégalités et justice sociale. Esprit, Paris, n. 182, p. 47-57, juin 1992.

HEGEL, Georg Wilhelm Friedrich. Ciencia de la Lógica. $3^{\mathrm{a}}$ ed. Buenos Aires: Solar/Hachette, 1974. 754 p.

LENOIR, René. Les exclus: un français sur dix. Paris: Seuil, 1974.

Martins, José de Souza. Exclusão social e a nova desigualdade. São Paulo: Paulus, 1997. 141 p. (Coleção temas de atualidade).

MARX, Karl; ENGELS, Friedrich. Marx \& Engels Werke (MEW). Berlin: Dietz Verlag, 1956-2000. $47 \mathrm{v}$.

MARX, Karl. O Capital: crítica da economia política. São Paulo: Abril Cultural, 19831985. 3 v. (Os Economistas).

MERRIEN, François-Xavier. État-providence et lutte contre l'exclusion. In: PAUGAM, Serge (Org.). L'exclusion, l'état des savoirs. Paris: Éditions La Découverte, 1996. p. 417-427.

NASCIMENTO, Elimar Pinheiro do. Globalização e exclusão social: fenômenos de uma nova crise da modernidade? In: DOWBOR, Ladislau; IANNI, Octavio; 
RESENDE, Paulo-Edgar A. (Orgs.). Desafios da globalização. Petrópolis: Vozes, 1997. p. 74-94.

OLIVEIRA, Luciano. Os excluídos 'existem'? Notas sobre a elaboração de um novo conceito. Revista Brasileira de Ciências Sociais, v. 12, n. 33, p. 49-61, fev. 1997b.

OLIVEIRA, Neiva Afonso. Rousseau e Rawls: contrato em duas vias. Porto Alegre: Edipucrs, 2000. 238 p. (Coleção Filosofia, 109).

PAUGAM, Serge (Org.). L'exclusion, l'état des savoirs. Paris: Éditions La Découverte, 1996. 584 p. (Collection Textes à l'appui).

Abordagem sociológica da exclusão. In: VÉRAS, Maura Pardini Bicudo (Org.). Por uma sociologia da exclusão social: o debate com Serge Paugam. São Paulo: Educ, 1999a. p. 49-62.

La constitution d'un paradigme. In: savoirs. Paris: Éditions La Découverte, 1996. p. 7-19.

(Org.). L'exclusion, l'état des

O enfraquecimento e a ruptura dos vínculos sociais: uma dimensão essencial do processo de desqualificação social. In: SAWAIA, Bader (Org.). As artimanhas da exclusão: análise psicossocial e ética da desigualdade social. Petrópolis: Vozes, 1999b. p. 67-86.

Pobreza, exclusão e desqualificação social: resumindo o debate europeu. In: VÉRAS, Maura Pardini Bicudo (Org.). Por uma sociologia da exclusão social: o debate com Serge Paugam. São Paulo: Educ, 1999c. p. 115-125.

PERCY-SMITH, Janie (Ed.). Policy responses to social exclusion: towards inclusion? Buckingham: Open University Press, 2000. 244 p.

ROCHA-COUTINHO, Maria Lúcia. Educação e violência simbólica: a exclusão social nas megacidades. Tempo Brasileiro, Rio de Janeiro, n. 120, p. 25-34, 1995.

SAWAIA, Bader (Org.). As artimanhas da exclusão: análise psicossocial e ética da desigualdade social. Petrópolis: Vozes, 1999. 160 p. (Coleção Psicologia Social).

SCHNAPPER, Dominique. Intégration et exclusion dans les sociétés modernes. In: PAUGAM, Serge (Org.). L'exclusion, l'état des savoirs. Paris: Éditions La Découverte, 1996. p. 23-31.

SEVERINO, Antônio Joaquim. Filosofia da Educação: construindo a cidadania. São Paulo: FTD, 1994. 152 p. (Coleção Aprender \& Ensinar)

SILVER, Hilary. Reconceptualizing social disadvantage: three paradigms of social exclusion. In: RODGERS, Gerry; GORE, Charles; FIGUEIREDO, José B. (Orgs.). Social Exclusion: rethoric, reality, responses. Geneva: International Labour Organization (International Institute for Labour Studies), 1995. p. 57-80.

SPOSATI, Aldaíza. Exclusão social abaixo da linha do equador. In: Véras, Maura Pardini Bicudo (Ed.). Por uma sociologia da exclusão social: o debate com Serge Paugam. São Paulo: EDUC, 1999. p. 126-138.

THOMAS, Hélène. La production des exclus: politiques sociales et processus de désocialisation socio-politique. Paris: PUF, 1997. 215 p. (Collection Sociologie d'aujourd'hui). 
TOLEDO, Roberto Pompeu de. Pacotes, excluídos e emergentes. Veja, São Paulo, 14 out. 1998, p. 154.

TOURAINE, Alain. Face à l'exclusion. Esprit, Paris, n. 169, p. 7-13, fév. 1991.

Os novos conflitos sociais: para evitar mal-entendidos. Lua Nova, São Paulo, n. 17, p. 5-18, jun. 1989.

VÉRAS, Maura Pardini Bicudo (Org.). Por uma sociologia da exclusão social: o debate com Serge Paugam. São Paulo: Educ, 1999. 142 p.

VERÍSSIMO, Luis Fernando. Nós os colaterais. Zero Hora, Porto Alegre, 12 maio 1999, p. 3.

WACQUANT, Loïc J. D. Proscritos da cidade: estigma e divisão social no gueto americano e na periferia urbana francesa. Novos Estudos Cebrap, n. 43, p. 64-83, nov. 1995.

XIBERRAS, Martine. As teorias da exclusão: para uma construção do imaginário do desvio. Prefácio de Julien Freund. Lisboa: Instituto Piaget, 1993. 251 p. (Epistemologia e Sociedade, 41).

Texto recebido em 14.01.04 e aprovado em 30.03.04 